\title{
A Brief Discussion on Construction of Information Commons and Subject Service Innovation
}

\author{
Maoli $X U^{1, a}$ \\ ${ }^{1}$ Library,Jilin Agricultural University,Changchun,130118,China \\ a email:xmljlau@yeah.net
}

Keywords: Information Commons, Subject Service, Innovation

\begin{abstract}
Subject service is one of the breakthrough points for university libraries to meet the requirements of information environment in the new era and information commons is one of the most important approaches for such innovation of service for those libraries. With further development of the subject service, it is an urgent need to search for breakthrough points of subject service complying with the new information environment.
\end{abstract}

\section{Introduction}

Information commons is a new and dynamic information service mode originated in university libraries in the USA in the 1990s, and a new practical service mode integrating information technology with digital resources and service resources. The initial information commons was merely a study room for researching, studying and writing of students, but along with advancement of information technology, enrichment of information resources and diversity of user demand, it gradually developed into a brand-new service mode that could not only provide various kinds of information services but also enable good communication with librarians. The information commons mainly plays an important role in promoting information sharing, mutual ownership and freedom of information, and provides integrated, share-based information service in dynamic development. Thus, it fully meet the needs of independent learning and scientific research of the users and satisfy the requirements of one-stop service in the whole process including information identification, retrieval, storage, processing and utilization.

\section{Change of Service Concept}

In recent years, libraries directors have gradually broken the normal multi-department setting as per individual function and discarded the independent service, isolated service and decentralized service pattern and changed the inefficient service in lack of collaborative communication among among the departments in order to improve the increasingly diversified service demand of readers, strengthen the mutual interaction between information resources, library spatial and information service personnel to enable the various departments to provide direct service for readers via information commons in a unified manner. At the same time, the service concept has been changed from"collections-centered" into "readers-centered" and along with the integration of library space, information resources and inquiry librarians, a new interactive service environment with "readers-librarians, readers-readers" collaborative learning and work has been built. The libraries integrated traditional reference service and subject service into learning and research process of teaching and scientific researches to drive knowledge innovation and provide best service for teaching and scientific researches.

\section{Characteristics of Subject Service in Construction of Information Commons}

Initiative and instructive subject service

Initiative and instructive characteristics are the fundamental factors for existence and development of information commons (IC) and also the requirements of service innovation for 
libraries. The library directors shall actively carry out cooperation with academic pacesetter in key subjects and projects and enable the subject librarians to actively participate in teaching and scientific research activities to serve as subject teaching assistants, subject consultants, project members and research partners to utilize IC subject service. Besides, IC shall be closely related to classroom and school life of students, such as attracting teachers and students to IC by construction of discussion group on a certain topic, subject -centered community, interest group and subject blog and guide them to use subject service to help themselves in learning and scientific researches.

Specialized subject service

Subject service in information commons of university libraries shall be firstly based on practical conditions of the university and provided with a general development target and program in order to promote specialized service mechanism, get the picture of subject development, teaching \&scientific researches, and the latest research trends and information. On this basis, the libraries directors shall give a full play to the subject librarians and collect complete data and conduct further processing in combination with the information resources collections in preparing secondary tertiary literature. Meanwhile, a comprehensive management service platform -- subject information service system shall be built, which can integrating various subject information elements such as database of academic subject, subject videos, teaching courseware, academic reports and academic works of the teachers and students of the university to ensure richness, provide deeper subject service for the readers and promote development in teaching and scientific researches of key subjects.

Sharable information resources

The libraries directors shall master general condition of construction of Information resources and setting of subjects of various schools and departments. Subject librarians shall communicate with the leaders of the schools and departments and teaching and scientific research personnel to reach the cooperation on common construction and sharing of information resources based on information need of scientific researchers and realize resources sharing between the libraries and the schools and departments, so as to enrich variety of professional literature for the subjects in information commons.

Dynamic subject service

With the diversification of approaches to obtain information and the needs of users, advantages of subject service in information commons of universities libraries began to be seen in its dynamic service, which is shown in mode and content of subject service in IC. IC is a platform for information gain and service increment, in which, the subject service can not only react to change in users needs with the latest theory and techniques in a timely manner, thus, IC integrates the subject service into learning and research process of the users, but also adjust service mode and update service content in good time to adapt to development of users needs, thus, it gives a full play to subject service.

\section{Innovation of Service in University Libraries under Information Commons}

It is necessary to strengthen competency in information literacy to realize service innovation

Information commons requires not only a good handling of operation service and user service in the library of the librarians, but also improvement of the business literacy of librarians and information literacy of readers. More important, librarians shall do a good job in helping the readers to utilize library. An era of knowledge economy and information network has come, we need to efficiently process and absorb the information we need in a timely manner, take in new knowledge and update old knowledge continuously to keep up with the development of the times and changes of society. Thus, it becomes necessary for the librarians and readers to strengthen information literacy and life-long learning of basic skills, namely, the ability to utilize information tools and information resources, including selection, acquisition, identification, processing, transmission and information creation.

It is a premise for information commons to establish the concept of equality

The foresaid equality refers to relations on an equal basis among students, teachers and librarians 
for that ,the readers can only complete the whole process of collaborative learning, research learning and cooperative learning and other activities on a basis of equality of the three parties.

It is the key for realization of information commons to enable cooperation among various parties.

The library service covers a complete dynamic service process, and service in information commons is multi-disciplinary, multi-technology and diversified comprehensive, requiring cooperation among various parties. Thus, the libraries directors shall exercise people-oriented management to realize harmonious environment.

Information service is a process with joint participation of students, teachers and librarians

The librarians shall regain the initiative in reception of all the readers,. engage themselves in each link of the whole information service together with the readers and can listen to the comments and suggestions on every service task of readers. Readers are actually owners of the library, the leadership and librarians of the library make efforts to help the readers, thus, they should be informed of any comments and suggestions on their service so that they can adjust the work principles and service mode to ensure continuous improvement of the service provided in the library.

To improve knowledge and service innovation with the information sharing platform

Under the information commons, users shall grasp the golden opportunity to truly realize sharing of human resources, knowledge, information and resources by independent learning, collaborative learning, team discussion and group research. The barrier-free service in high quality is good for motivating the readers and librarians can be motivated in inspiration in learning and work enthusiasm so as to realize knowledge and service innovation.

It is a driving source for innovation of service in libraries to build learning-aimed library.

Construction of learning-aimed library helps to create the academic atmosphere of the whole library, promote knowledge communication and regeneration for it harbors characteristics such as continuous learning, close cooperation, connected network, collective sharing concept, spirit of innovation and development and method of system thinking. On this basis, it is an inevitable trend to build learning-aimed library and the driving source for innovation of service in libraries under information commons.

\section{Conclusions}

The information commons is totally brand new to us, and there are some essential differences between traditional libraries and libraries with information commons libraries in service concept, content, mechanism, mode and management mode. Under this circumstance, the dynamic service system in rapid development provides us an important opportunity for service innovation and it is of vital importance for enhancement of core business competitiveness of libraries, improvement of teaching and scientific research level and subject construction of universities.

\section{Acknowledgment}

In this paper, the research was sponsored by the Project of 2016 CALIS National Literature Information Center, named "A Study on Construction of Information Commons for Subject Service in University Library "(2016026),Jilin Province Science of Education “12th five-year” planned project "Construction and Implementation of University library Resources and Service Support Platform for Key Subjects”(GH150212), Research project for higher education scientific launched by Jilin institute of Higher education in 2015, named"A Study on Construction of Information Commons based on Featured \& Leading Subjects " (JGJX2015D31)and The "13th five-year" social science research project of the Education Department of Jilin Province, named" A Study on Construction of Information Commons in University Library for Major Subject Construction "(2016019). 


\section{References}

[1] Xie Shoumei, A Study on Embedded Subject Service under Ubiquitous Knowledge Environment[J], Library Work and Research,2013

[2] Zhang Delin, Embedded Subject Service of University Library [J],Journal of Library Science, 2012

[3] Yang Weiqi, Embedded Subject Service - New Thoughts of Transformation Development of Research-oriented University Library [J], Information and Documentation Services, 2012

[4] Li Yuan, Liu Jianguo, A Study on Bottlenecks in Construction of Information Commons in University Library [J], Journal of Library Science, 2010

[5] Guo Haiming, Library Spatial Service Under the Concept of Resources Sharing [J],, Library Theory and Practice, 2011 